University of Nebraska - Lincoln

DigitalCommons@University of Nebraska - Lincoln

2015

\title{
Racial Differences in Job Attribute Preferences: The Role of Ethnic Identity and Self-Efficacy
}

Jakari N. Griffith

Gwendolyn M. Combs

Follow this and additional works at: https://digitalcommons.unl.edu/managementfacpub

Part of the Business Administration, Management, and Operations Commons, Management Sciences and Quantitative Methods Commons, and the Strategic Management Policy Commons

This Article is brought to you for free and open access by the Management Department at DigitalCommons@University of Nebraska - Lincoln. It has been accepted for inclusion in Management Department Faculty Publications by an authorized administrator of DigitalCommons@University of Nebraska - Lincoln. 
Bridgewater State University

\section{Virtual Commons - Bridgewater State University}

2015

\section{Racial Differences in Job Attribute Preferences: The Role of Ethnic Identity and Self-Efficacy}

Jakari N. Griffith

Bridgewater State University, jakari.griffith@bridgew.edu

Gwendolyn M. Combs

University of Nebraska-Lincoln

\section{Virtual Commons Citation}

Griffith, Jakari N. and Combs, Gwendolyn M. (2015). Racial Differences in Job Attribute Preferences: The Role of Ethnic Identity and Self-Efficacy. In Management Faculty Publications. Paper 37.

Available at: http://vc.bridgew.edu/management_fac/37 


\title{
Racial Differences in Job Attribute Preferences: The Role of Ethnic Identity and Self-Efficacy
}

\author{
Jakari N. Griffith \\ Bridgewater State University \\ Gwendolyn M. Combs \\ University of Nebraska-Lincoln
}

Using a sample of 149 white and 190 black business students, the authors examined racial differences in job attribute preferences. Results of this study indicate there were significant racial differences in 19 of 21 job attributes examined, with black students placing greater importance on job attributes than white students. Investigation of the mechanisms contributing to this difference reveals that the relationship between race and job attribute preferences was mediated by ethnic identity. Furthermore, the relationship between ethnic identity and job attributes was moderated by personal efficacy, with higher self-efficacy levels leading to greater importance placed on job attributes.

\section{INTRODUCTION}

Organizations have demonstrated and expressed a critical need to enhance their workforce diversity (Bell, 2011; Roberson, 2006). Human capital diversity is perceived as a strategic focus designed to positively impact organizational problem solving processes, attractiveness to diverse markets, and overall competitive advantage (Richard, 2000). To achieve workforce diversity, organizations intentionally engage in recruitment efforts that pull from diverse labor pools (McKay \& Avery, 2005).

Organizations use various strategies to attract African American and other racial/ethnic minorities. These strategies include applicant and recruiter similarity (Turban \& Dougherty, 1992), presence of highlevel diversity programs (Braddy, Meade, \& Kroustalis, 2006; Lillevik, Combs, \& Wyrick, 2010), targeted and welcoming recruitment (McKay \& Avery, 2005), and campus visits seeking applicants of choice (Rynes \& Boudreau, 2006; Turban, 2001). Yet, as organizations attempt to compete for African American and other diverse workers, applicants are less able to identify meaningful differences between firms due to increasing conformity in recruitment strategies (Avery \& McKay, 2006).

There are two specific theoretical perspectives that firms can draw on to overcome the effects of these competitive pressures. One theoretical perspective advances that job attributes, defined as characteristics or qualities of work (e.g., responsibility, developing skills, and autonomy), can be used to positively influence applicant's decision to consider or accept employment with a particular organization Konrad, Ritchie, Lieb, \& Corrigall, 2000). The second perspective argues that identity related constructs positively influence job choice decisions, and thus can be used to recruit across diverse labor force groups (ChrobotMason \& Thomas, 2002). Despite calls for examining job attributes preferences and identity constructs together (Combs, Milosevic, Jeung, \& Griffith, 2012), little consideration has been given to 
understanding the joint impact of these variables on the attraction of diverse workers. As Avery and McKay (2006), note, "if practitioners truly wish to diversify their companies' workforces, it is imperative that they convey to minority and female job seekers that their distinctive identities will be valued" (p.177).

Although a small number of studies have demonstrated racial differences between African Americans and whites on their preferences for particular job attributes (Brenner \& Tomkiewicz, 1982; Brenner, Blazini, \& Greenhaus, 1988), these studies have largely overlooked the impact and significance of ethnicity and related cognitive variables. We attempt to fill this gap by examining racial differences in job attribute preferences from the theoretical perspective of ethnic identity (Phinney, 1992; Phinney \& Ong, 2007) and self-efficacy (Bandura, 1997). The combined focus on identity and efficacy is important because it begins to specify the motivational and cognitive mechanisms capable of explaining racial differences in job attribute preferences (Avery \& McKay, 2006; Helms, 1994). Furthermore, we address the call for additional research on effective methods for obtaining an appropriate return on investment through the attraction and retention of diverse hires (McKay, Avery, Tonidandel, Morris, Hernandez and Hebl, 2007). Organizations that are knowledgeable of differing job attributes preferences may be in a better position to influence job choice decisions of minority applicants in relation to person-job and person-organization fit (Chapman, Uggerslev, Carroll, Piasentin \& Jones, 2005; Karasek \& Bryant, 2012; Butler, Sanders \& Whitecotton, 2000).

Thus, we first examine the current state of job attribute preferences by examining the extent to which racial differences exist between African American and white college students in evaluations of job attributes. Next, we explore the mediating role of ethnic identity in the relationship between race and preferences for job attributes. And finally, we seek to determine whether self-efficacy forms a moderating link between ethnic identity and job attribute preference. We offer and test a set of hypotheses reflecting these proposed relationships. Our sampling frame focused on college business students because these individuals would likely have significant exposure to and knowledge of the importance of job attributes as part of their curriculum. Moreover, college students from diverse racial and ethnic backgrounds are an important part of the labor force that are often tapped by recruiters to meet long-term diversity recruitment goals (Doverspike, Taylor, Shultz, \& McKay, 2000).

\section{LITERATURE REVIEW AND HYPOTHESES}

The following is a review of the literature regarding job attributes and job attribute preference, ethnic identity and self-efficacy. We present hypothesis indicating the relationships we propose and test regarding the study variables.

\section{Job Attributes}

Job attributes are defined as characteristics or qualities of work (e.g., responsibility, developing skills, and autonomy) that may influence career growth and development (Konrad et al.2000). Job attributes are important because they are observed to be significant indicators of decisions to reject or accept an employment offer (Beaty, 1990; Turban, Eyring \& Campion, 1993). Yet in spite of their potential to influence employment choices, recruitment and retention practices suffer because little is known about the preferences of potential employees from diverse backgrounds. Empirical studies suggest that while all students from diverse backgrounds value similar employment goals (Lee \& Rojewski, 2009), African American students in particular may perceive significant employment barriers tied to their group membership, which, in turn, influences their examination of work environments in search of factors that support their career and personal work goals (Hughes \& Demo, 1989). Barriers include fears around confirming negative stereotypes (Aronson \& Steele, 2005), experiencing discrimination (Oyserman, Uskul, Yoder, Nesse, \& Williams, 2007), and feeling unsupported (Oyserman, Brickman, Bybee, \& Celious, 2006). These and other barriers may significantly impact the kinds of attributes African American applicants seek in considering employment (Baumeister \& Leary, 1995). 
Although racial differences in job attributes have been examined in several studies in the 1980s and '90s (for example see Brenner \& Tomkiewicz, 1982; Brenner, Blazini, \& Greenhaus, 1988), there is very little evidence to substantiate whether racial differences in job attribute preferences persist in current or contemporary employment environments. It is espoused that racism no longer manifests in social, employment and economic landscapes in America and that race relations have greatly improved among younger generations. However, a recent report by the Greenlining Institute states that blacks continue to perceive a high degree of racism while whites do not, providing further evidence that we may not live in a truly post-racial environment (Byrd \& Mirken, 2011).

Research studies frequently regard race as an important predictor of social economic status (SES) and often point out that economic disadvantage can be attributed to the historical lag in occupational and educational outcomes for certain racial groups (House \& Williams, 2000). For example, although all college graduates suffered during the recent recession beginning in 2008, data reveals that African American college graduates were more adversely affect than all other college graduates in terms of unemployment and underemployment. For example, Jones and Schmidt (2014) report that African American college graduates experienced higher levels of unemployment (up from 7.8 to $12.4 \%$ between years 2007 and 2013 compared to $2.3 \%$ to $5.6 \%$ for all other graduates). Underemployment status for African American college graduates reflects just one devastating statistic. Additionally, due to lower labor force participations rates of African Americans (e.g., high unemployment and underemployment rates and job segregation), we suspect that in contemporary work environments, perceived racial differences in job attributes preferences may be important considerations for African Americans and these preferences may differ from those considered important by whites

Therefore, given the ages of previous studies, the rate of unemployment and underemployment of college graduates, and recent debate regarding "post racial social and work environments, there is a need to examine whether differences between African American and white college students' job attribute preference still exist. Thus, we hypothesize that:
Hypothesis 1: There is significant difference in job attribute preferences between African American and white college students with African American college students being more likely to rate the importance of individual job attributes higher than white college students.

\section{Ethnic Identity}

Previous research examining differences between black and white students on job attribute preference has primarily focused on race as a sole determining factor (Brenner \& Tomkiewicz, 1982; Brenner, Blazini, \& Greenhaus, 1988). In this study, we build on previous research by examining whether racial differences in job attribute preferences can be explained by the cognitive properties of ethnic identity. Unlike racial identity, which "refers to a sense of group or collective identity based on one's perception that he or she shares a common heritage with a particular and specific racial group" (Helms, 1993, p. 3), or race which considers phenotypic differences between groups as the basis for inferring causation or agency (Helms, 1994), ethnic identity is commonly portrayed as a global measure (Cokley, 2007; Phinney, 1992) assessing a person's sense of identification with an ethnic group with whom he or she shares common traditions, values, and cultural understandings (Chavez \& Guido-DiBrito, 1999). Ethnic identity focuses on how people integrate knowledge of group membership into the self-concept (Avery, Tonidandel, Thomas, Johnson, \& Mack, 2007; Phinney, 1992), and thus factors in identity-based concerns such as the prevalence of group stereotypes and perceived status differences between ethnic groups.

Furthermore, research indicates that individuals tend to process information and regulate behavior in relation to how their group is represented (or perceived) in society (Block, Koch, Liberman, Merriweather, \& Roberson, 2011; Fouad \& Byars-Winston, 2005; Phinney \& Alipuria, 1996). When a group's identity has negative status, theory suggests that group members will pursue strategies that increase their access to valued resources, which enhance the prospect of achieving positive identity status. 
More specifically, ethnic identity not only provides a structure that shapes one's perspective about self in relation to others, but it also functions as a primary mechanism influencing interpretations, judgments, and action. Applying this logic to job attribute preferences, we contend that applicants' attraction to certain job attributes may actually derive from identity-related motivation, centered on maintaining or improving perceived differences in opportunity structure (Carter, Gushue, \& Weitzman, 1994; Oyserman $\&$ Destin, 2010). Even though race may relate to these structures and perceptions, we argue that ethnic identity may illuminate an underlying cognitive variable that offers a more complex and nuanced perspective regarding traditional approaches to the study of race and job attributes (Grills \& Prus, 2008; Helms \& Piper, 1994; Helms \& Talleyrand, 1997).

Ethnic identity has been conceptualized as both a predictor and moderator in some empirical examinations. However, research has also shown that the psychological properties supporting ethnic identity make it amenable to investigations of meditational affects in racial comparative studies. For example, Brittian, Kim, Armenta et al. (in press) found that the relationship between perceived group discrimination and depressive symptoms was mediated by ethnic identity for Latino students, but not for blacks. Similarly, Swanson and Prelow (2005) found that ethnic identity played a partial mediating role in explaining the connection between perceived self-efficacy and supportive parenting. Neblett, Banks, Cooper, and Smalls-Glover (2013) also demonstrate that ethnic identity mediated the relationship between socialization processes and depressive symptoms. Scholars have also affirmed that ethnic identity has great utility for persons self-identifying as "white" to the extent it encompasses how identity facets are constituted in the self-concept with respect to the meaning of race (McDermott \& Samson, 2005). For example, McDermott and Samson argue that white ethnic identity can be understood as an explanatory variable for presumed structural privilege or the desire to distance oneself from whiteness. Given these studies, empirical investigation of ethnic identity as a meditational variable satisfies calls for a more nuanced understanding of racial differences in the general context of management studies, and job attribute preferences in particular. Thus, we offer the following hypothesis:

\section{Hypothesis 2: Ethnic identity will mediate the relationship between race and job attribute preferences.}

\section{Self-Efficacy Beliefs}

A third goal of this study was to assess whether job attribute preferences are influenced by selfefficacy beliefs. Bandura (1997) defines self-efficacy as a person's belief in his or her ability to marshal the necessary cognitive and affective resources required for goal achievement. Vocational research has examined the influence of self-efficacy and ethnic identity on career decision-making. For example, Gushue (2006) found that individual perceptions of efficacy to engage in career exploration related positively and significantly to ethnic identity. Moreover, Gloria and Hird (1999) established that ratings for both ethnic identity and career decision-making self-efficacy differ significantly when compared by race.

These studies provide two important insights into the potential influence of efficacy on the relationship between ethnic identity and job attribute preferences. First, given that ethnic identity is a function of the internalization of identity-related information (good and bad) into the self-concept, potentially a person in a low-status group may view job attribute assessment from the perspective of conduits to improved social or economic standing. Second, we argue that people responding from the perspective of low status may experience varying levels of personal agency (Hughes \& Demo, 1989), which imposes an efficacy dimension on the selection of job attributes. Our argument is based on Fouad and Brown's (2000) research, which suggests that a person may accept (or internalize) the legitimacy of group differences and feel unable to change the nature of those relationships because they are perceived to be relatively fixed and stable. On the other hand, a person may view status differences between groups as illegitimate and surmountable. Such a view may afford those with greater efficacy a chance to change social relations through selective consideration of job attributes that support perceptions of improved status or those that facilitate access to greater opportunities. 
Although African American college students may be more sensitive to the status position of their group and view structures of opportunity differently, research shows college education produces higher levels of efficacy for black students than it does for whites (Hughes \& Demo, 1989). Since self-efficacy theory argues that high-efficacy individuals will invest more time in preparatory activities designed to improve their chances of success (e.g., seeking out supportive resources), we suggest that differences in estimations of personal efficacy should lead to a differential evaluation of job attributes that might impact future performance (Bandura, 1997). For individuals concerned that environmental constraints might deprive them of the ability to exercise their full work potential (Kim \& Gelfand, 2003; Leong \& Chou, 1994), self-efficacy theory holds that those feeling most confident will attempt to change aspects of the environment in ways that allow them to better utilize their skills (e.g., joining work projects of high importance to the organization) (Bandura, 1997).

The above conceptualization is especially relevant to the examination of job attribute preferences because it suggests that organizational characteristics, such as those represented by job attributes, may not only be influenced in an identity-congruent fashion (Linnehan, Chrobot-Mason, \& Konrad, 2006), but may also mutually depend on varying influences of self-efficacy (Gushue, 2006). Furthermore, while many studies have investigated the connection between ethnic identity and efficacy on overall assessments of career outcomes, there have been no examinations of these variables in relation to specific features of work. Thus, understanding the theoretical relationships between these variables may significantly improve our ability to determine when and how job attributes might be utilized to facilitate the career development and job attraction of underserved populations.

Hypothesis 3: Self-efficacy will moderate the relationship between ethnic identity and job attribute preferences.

\section{METHOD}

\section{Sample and Procedure}

A total of 404 college students were solicited from 13 colleges and universities in the Southwestern and Midwestern United States. Our final sample consisted of 149 white/Caucasian and 190 black/African American participants, with the following demographics: 19-23 years of age $(n=253), 24-27$ years $(n=$ $55), 28-32$ years $(\mathrm{n}=14)$, and $33+$ years $(\mathrm{n}=17)$. There were 203 women and 134 men with 2 no reports; 213 of the participants reported being college juniors, 84 seniors, 15 sophomores, 17 freshmen, and 10 graduate students. A total of 67 students provided incomplete data for more than one survey item; however, participants who did provide complete data were not significantly different from those who did not in terms of gender $(\mathrm{t}(378)=.029, \mathrm{~ns})$, age $(\mathrm{t}(380)=-0.137, \mathrm{~ns})$, employment status $(\mathrm{t}(380)=1.36$, $\mathrm{ns})$, ethnic identity $(\mathrm{t}(391)=.290, \mathrm{~ns})$, self-efficacy $(\mathrm{t}(375)=-0.091, \mathrm{~ns})$, and job attribute preference $(\mathrm{t}$ $(402)=.713, \mathrm{~ns})$.

Data were captured using an online survey. Students were invited to participate using an email with a study URL supplied by the researcher. They were not compensated for their involvement, but were told that participation might provide research insight and inform practitioner policies and decisions. Students were assured that their responses would remain completely anonymous and confidential.

\section{Measures}

Demographic Information

Basic demographic information was collected from participants at the end of the online survey. This included age, gender, education, employment status, and race. Race was dummy coded 0 and 1, which reflected white and black respectively.

\section{Ethnic Identity}

Evaluations of ethnic identity were established using Phinney's (1992) Multi-group Ethnic Identity Measure (MEIM). This contains 12 items and is set on a 4-point scale ranging from strongly agree to 
strongly disagree. The items subject to analysis in the present study are specific to ethnic identity search. Sample items include: "I think a lot about how my life will be affected by my ethnic group membership"; and "I have spent a lot of time trying to find out more about my ethnic group, such as its history, traditions, and customs." Reliability alpha $=.80$.

\section{Self-Efficacy}

A measure of self-efficacy was drawn from Luthans, Youssef, and Avolio's (2007) Psychological Capital Questionnaire (PCQ). The questionnaire contains 24 items reflecting factors of hope, optimism, resilience, and efficacy, and was anchored on a 7-point Likert scale ranging from "strongly disagree" to "strong agree." The PCQ items are designed to relate to the workplace domain in general. In this study we used six items representing self-efficacy, including: "I feel confident helping to set/target goals"; and "I feel confident presenting information to a group of colleagues." Reliability alpha $=.91$.

\section{Job Attribute Preferences}

We measured job attribute preferences using a 21-item scale adapted from Meyer, Irving and Allen (1998) that was based on a 25-item scale developed by Manhardt (1972). The scale represents an assortment of job attributes relevant for contemporary evaluations of employment. It was anchored on a 5-point Likert scale ranging from "not important" to "very important." Representative items include the degree to which you expect that your job will "provide opportunities to earn a high income" and "encourage continued development of knowledge and skills." Reliability alpha $=.87$

\section{Control Variables}

We included gender, age, and employment status as control variables. We incorporate gender in our analysis because it has been shown to relate to job attribute preferences (Konrad et al., 2000). Because work exposure would likely impact perceptions of job attribute preferences, we included whether applicants were currently employed. We included age in our analysis because number of potential years employed in the workforce may have had an impact on evaluations of job context (Rynes, Heneman, \& Schwab, 1980). Gender, age, and employment status were self-reported by participants and used as control variables for the various analyses.

\section{RESULTS}

\section{Descriptive Statistics}

As evidenced in the correlation matrix in Table 1, we found a positive relationship between ethnic identity and job attribute preference $(r=.422, p<.00)$, perceived self-efficacy $(r=.507, p<.00)$, and racial category groupings $(r=.388, p<.00)$. The results of the correlational analysis are important because they support the significantly positive relationship between ethnic identity and the associated study variables of race, self-efficacy, and job attribute preferences. 


\section{DESCRIPTIVE STATISTICS, CORRELATIONS, AND SCALE RELIABILITIES}

\begin{tabular}{llllllllll}
\hline & $\mathrm{M}$ & $\mathrm{SD}$ & 1 & 2 & 3 & 4 & 5 & 6 & 7 \\
1. Job Attributes & 4.03 & .47 & -- & & & & & & \\
2. Ethnic Identity & 2.78 & .73 & $.42^{* *}$ & -- & & & & & \\
3. Self-Efficacy & 4.89 & .96 & $.51^{* *}$ & $.33^{* *}$ & -- & & & & \\
4. Race & 0.56 & .49 & $.39^{* *}$ & $.59^{* *}$ & $.31^{* *}$ & -- & & & \\
5. Gender & 1.60 & .49 & $.12^{* *}$ & $.15^{* *}$ & -.06 & $.16^{* *}$ & -- & & \\
6. Age & 1.43 & .94 & .03 & -.03 & .05 & $.20^{* *}$ & .06 & - & \\
7. Employment & 1.52 & .76 & .01 & .03 & .06 & .01 & .09 & -.01 &
\end{tabular}

${ }^{*} p<.05 ;{ }^{* *} p<.01$ Note. $N$ for Job Attribute Preferences $(\mathrm{N}=404)$, Ethnic Identity Search $(\mathrm{N}=393)$, SelfEfficacy $(\mathrm{N}=377)$, Race $(\mathrm{N}=337)$, Gender $(\mathrm{N}=380)$, Age $(\mathrm{N}=382)$, and Employment $(\mathrm{N}=382)$. Correlations are found on the diagonal. The race variable was coded 0 for whites and 1 for African Americans.

\section{ANOVA Analyses}

To examine the extent to which racial differences existed in the study variables of interest, we conducted a one-way ANOVA using race as the independent variable, and the composite measure of job attribute preferences, the individual facets of the job attribute preferences measure, and ethnic identity as the dependent variables. The ANOVA analyses found significant differences between African American students and whites on 19 of the 21 individual job attributes examined (see Table 2). In particular, the results showed that the largest mean differences occurred for items stressing the need for clear-cut rules and procedures $F(1,335)=47.24, \mathrm{p}<.000$; attributes that emphasize culture and aesthetic values $F(1$, $337)=17.33, \mathrm{p}<.000$; and a desire for intellectually stimulating work $F(1,337)=30.51, \mathrm{p}<.000$. There were no significant differences between African American and white students on the individual items that focused on ample leisure time off $F(1,333)=2.16, \mathrm{p}<.000$; jobs providing security $F(1,333)=3.15, \mathrm{p}<$ .000 ; and the ability to supervise others $F(1,333)=.026, \mathrm{p}<.000$. With respect to the composite (or global) measure of job attribute preferences, blacks $(\mathrm{M}=4.16, \mathrm{SD}=.47)$ placed greater value on overall job attribute preferences than whites $(\mathrm{M}=3.84, \mathrm{SD}=.42)$ such that there were statistically significant differences between the two groups $F(1,338)=43.34, \mathrm{p}<.000$.

The remaining ANOVA analyses demonstrated significant differences in reported levels of ethnic identity $F(1,333)=176.1, \mathrm{p}<.000$, with African American students $(\mathrm{M}=3.43, \mathrm{SD}=.43)$ scoring higher than whites $(\mathrm{M}=2.69, \mathrm{SD}=.51)$. Significant differences were also found for scores on self-efficacy $F(1$, $332)=34.15, \mathrm{p}<.000$; African American students reported significantly higher mean levels of efficacy $(\mathrm{M}=5.15, \mathrm{SD}=.91)$ than white students $(\mathrm{M}=4.56, \mathrm{SD}=.91)$. Based on the statistically significant findings, we establish that blacks rate higher on both composite (global) and item-specific measures of job attributes (19 out of 21 items), as well as measures of ethnic identity and self-efficacy. Thus, we establish support for hypothesis one. 


\section{TABLE 2}

ANOVA TESTS ON 21 JOB ATTRIBUTE DIMENSIONS, ETHNIC IDENTITY, EFFICACY AND TOTAL JOB ATTRIBUTES BY RACIAL GROUPING

\begin{tabular}{|c|c|c|c|c|c|c|c|}
\hline \multirow[t]{2}{*}{ Caucasian } & \multicolumn{3}{|c|}{ African American } & \multirow[b]{2}{*}{ S.D. } & \multirow[b]{2}{*}{$\mathrm{F}$} & \multirow[b]{2}{*}{$\mathrm{p}$} & \multirow[b]{2}{*}{$\eta 2$} \\
\hline & Mean & S.D. & Mean & & & & \\
\hline 1. Ample leisure time off & 3.94 & .93 & 4.10 & .98 & 2.16 & .14 & .01 \\
\hline $\begin{array}{l}\text { 2. Requires working on problems of } \\
\text { central importance }\end{array}$ & 3.48 & .82 & 3.91 & .88 & 20.93 & $.00 * *$ & .06 \\
\hline 3. Responsibility for taking risks & 3.35 & .90 & 3.69 & 1.00 & 10.16 & $.00 * *$ & .03 \\
\hline $\begin{array}{l}\text { 4. Allows you to make social } \\
\text { contribution }\end{array}$ & 3.91 & .88 & 4.24 & .81 & 12.34 & $.00 * *$ & .04 \\
\hline 5. Opportunities for high income & 4.22 & .83 & 4.59 & .71 & 19.63 & $.00 * *$ & .06 \\
\hline $\begin{array}{l}\text { 6. Encourages continued development } \\
\text { of knowledge/skills }\end{array}$ & 4.37 & .77 & 4.72 & .55 & 23.25 & $.00 * *$ & .07 \\
\hline 7. Provides security & 4.29 & .86 & 4.47 & .77 & 3.85 & $.05^{*}$ & .01 \\
\hline $\begin{array}{l}\text { 8. Provides feelings of } \\
\text { accomplishment }\end{array}$ & 4.38 & .69 & 4.63 & .65 & 11.57 & $.00 * *$ & .03 \\
\hline $\begin{array}{l}\text { 9. Lets you develop your own methods } \\
\text { for doing work }\end{array}$ & 3.82 & .81 & 4.10 & .78 & 9.86 & $.00 * *$ & .01 \\
\hline 10. Respected by other people & 4.14 & .76 & 4.54 & .71 & 24.05 & $.00 * *$ & .07 \\
\hline $\begin{array}{l}\text { 11. Requires meeting and speaking with } \\
\text { many people }\end{array}$ & 3.48 & .97 & 3.77 & 1.06 & 6.32 & $.01^{*}$ & .02 \\
\hline $\begin{array}{l}\text { 12. Permits a regular routine in time and } \\
\text { place of work }\end{array}$ & 3.41 & .98 & 3.73 & 1.12 & 7.25 & $.01^{*}$ & .02 \\
\hline 13. Clear-cut rules and procedures & 3.44 & .90 & 4.13 & .93 & 47.24 & $.00 * *$ & .12 \\
\hline 14. Satisfies cultural needs & 3.57 & .97 & 4.01 & .95 & 17.33 & $.00 * *$ & .05 \\
\hline 15. Intellectually stimulating & 3.91 & .81 & 4.36 & .69 & 30.51 & $.00 * *$ & .08 \\
\hline 16. Requires supervising others & 3.41 & .90 & 3.40 & 1.08 & .026 & .87 & .00 \\
\hline 17. Permits working independently & 3.74 & .87 & 4.05 & .95 & 9.55 & $.00 * *$ & .03 \\
\hline $\begin{array}{l}\text { 18. Advancement to higher } \\
\text { administrative positions }\end{array}$ & 4.10 & .87 & 4.48 & .77 & 18.06 & $.00^{* *}$ & .05 \\
\hline 19. Comfortable working conditions & 4.30 & .68 & 4.59 & .70 & 14.06 & $.00 * *$ & .04 \\
\hline 20. Change and variety in duties & 3.82 & .87 & 4.21 & .79 & 17.91 & $.00 * *$ & .05 \\
\hline 21. Requires creativity & 3.53 & .89 & 3.93 & .97 & 14.75 & $.00 * *$ & .04 \\
\hline 22. Ethnic Identity & 2.69 & .51 & 3.43 & .43 & 200.28 & $.00 * *$ & .37 \\
\hline 23. Self-Efficacy & 4.56 & .91 & 5.15 & .91 & 34.15 & $.00 * *$ & .09 \\
\hline 24. Job Attributes Total & 3.84 & .42 & 4.16 & .47 & 43.34 & $.00 * *$ & .10 \\
\hline
\end{tabular}

${ }^{*} p<.05 ; * * p<.01$ 


\section{Testing the Mediation Link}

To examine the proposed mediating role of ethnic identity, we implemented a path-analysis-based Macro developed by Hayes, Preacher, and Myers (2011) that examines mediation using a 95\% biascorrected bootstrap confidence interval. Before subjecting the variables to analysis, we centered each item to control for the effects of multicollinearity (Aiken \& West, 1991) and to ensure the coefficients were interpretable within the range of data (Hayes, Glynn, \& Huge, 2012). The primary focus of the mediation model was to first investigate the extent to which $\mathrm{M}$ (ethnic identity) carried the influence of the independent variable Race (dummy coded as $0=$ white, $1=$ black) to the dependent variable of job attribute preference. For the proposed mediation model to be significant, the affect of the independent variable on the dependent variable should be accounted for entirely by the mediator, as represented by a confidence interval exceeding zero. The bootstrapping results indicated that the indirect effect of race on job attribute preferences through ethnic identity was significant: $\mathrm{B}=.20, \mathrm{SE}=.04,95 \% \mathrm{CI}=[.12, .28]$, which suggests the relationship between race and job attributes is mediated by ethnic identity (see Table 3 ). Based on these statistically significant findings, we are able to provide support for the mediation proposed in hypothesis two.

\section{TABLE 3 \\ REGRESSION RESULTS AND MEDIATION TEST OF ETHNIC IDENTITY BETWEEN RACE TO JOB ATTRIBUTES}

\begin{tabular}{lllll} 
& $\mathrm{B}$ & $\mathrm{SE}$ & $\mathrm{t}$ & $\mathrm{p}$ \\
\hline Predictors & & & & \\
Constant & 3.21 & .13 & 24.07 & $.00^{* *}$ \\
Age $\rightarrow$ Job Attributes & .015 & .03 & .60 & .60 \\
Gender $\rightarrow$ Job Attributes & .043 & .05 & .86 & .38 \\
Employment $\rightarrow$ Job Attributes & -.00 & .03 & -.00 & .10 \\
Race $\rightarrow$ Job Attributes & .12 & .06 & 1.99 & $.05^{*}$ \\
Ethnic identity $\rightarrow$ Job Attributes & .24 & .04 & 5.73 & $.00^{* *}$ \\
Race $\rightarrow$ Ethnic identity & .85 & .07 & 13.13 & $.00^{* *}$ \\
Indirect effects & Effect & Boot SE & BootLLCI & BootULCI \\
Indirect effect of ethnic identity & .20 & .04 & .12 & .29 \\
\hline
\end{tabular}

Number of bootstrap samples: 5000; $95 \%$ Confidence Interval; $\mathrm{N}=332$

$* p<.05 ; * *<<.01$

\section{Testing the Moderation Link}

We suggest that self-efficacy will moderate the relationship between ethnic identity and job attribute preference. For the moderation to hold, a significant interaction term should result in the regression analysis, to suggest that the magnitude of ethnic identity effect on job attributes depends on a person's level of reported self-efficacy.

To help us assess this relationship, we examined the interaction pattern of ethnic identity at two levels of the moderator (self-efficacy) using an interaction plot (see Figure 1). As with the mediation analysis, we employed a Macro designed by Hayes, Preacher, and Myers (2011) that probes the interaction by estimating the conditional effect of ethnic identity at different values of self-efficacy.

The results of the simple moderation test demonstrated a significant interaction between self-efficacy and ethnic identity on job attribute preferences $(\mathrm{B}=.07, \mathrm{SE}=.28, \mathrm{t}=2.43, \mathrm{p}<.01)$. In support of our proposed moderation, the evaluation revealed that when self-efficacy was higher, respondents placed greater emphasis on the composite measures of job attributes $(\mathrm{B}=.23, \mathrm{SE}=.04,95 \% \mathrm{CI}=[.16, .30])$ as they approached higher levels of ethnic identification. When respondents reported lower levels of selfefficacy, the relationship was also significant $(\mathrm{B}=.09, \mathrm{SE}=.04,95 \% \mathrm{CI}=[.01, .18])$. Taken together, these results demonstrate significant support for the moderating hypothesis proposed in hypothesis three, 
which suggests that the impact of ethnic identity on job attributes varies at different levels of self-efficacy (see Table 4).

FIGURE 1

\section{INTERACTION OF SELF-EFFICACY AND ETHNIC IDENTITY ON JOB ATTRIBUTE PREFERENCES}

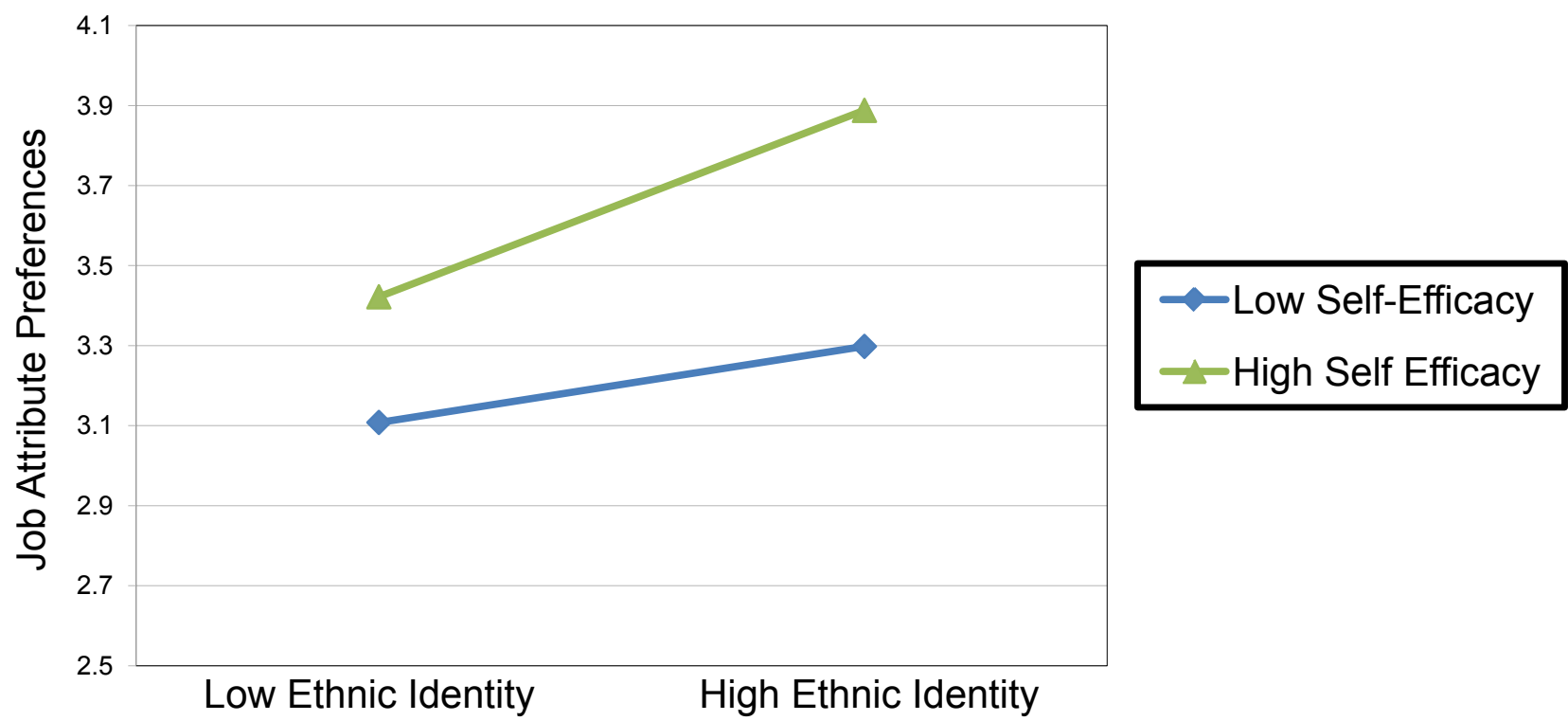

TABLE 4

REGRESSION RESULTS AND MODERATION TEST OF ETHNIC IDENTITY AND EFFICACY ON JOB ATTRIBUTES

\begin{tabular}{llllll} 
& $\mathrm{B}$ & $\mathrm{SE}$ & $\mathrm{t}$ & $\mathrm{p}$ & $R^{2}$ \\
\hline Predictors & & & & & \\
Constant & 3.42 & .11 & 31.37 & $.00^{* *}$ & \\
Age $\rightarrow$ Job Attributes & .01 & .02 & .27 & .79 & .00 \\
Gender $\rightarrow$ Job Attributes & .11 & .04 & 2.65 & $.01 *$ & .02 \\
Employment $\rightarrow$ Job Attributes & -.03 & .03 & -1.27 & .20 & .00 \\
Ethnic Identity $\rightarrow$ Job Attributes & .16 & .03 & 5.43 & $.00^{* *}$ & .18 \\
Self-efficacy $\rightarrow$ Job Attributes & .03 & .08 & .44 & .66 & .26 \\
Ethnic Identity X Self-efficacy & .07 & .03 & 2.42 & $.02 *$ & .36 \\
\hline
\end{tabular}

$\mathrm{N}=369 ;{ }^{*} p<.05 ; * * p<.01$

\section{DISCUSSION}

This study extends the job attributes literature by examining the intervening roles of ethnic identity and self-efficacy on job attribute preferences. First, our results replicate earlier research findings that suggest African American students desire more from their jobs than white students (Brenner \& Tomkiewicz, 1982). In particular, our results show that African American students scored higher than 
whites on both composite and 19 of 21 individual measures of job attribute preferences. When Brenner and colleagues assessed the job orientation of blacks and whites in 1982, they found that black students placed greater value than whites on 12 of 25 job attributes. Thus, our data suggest that the attribute preference gap has widened significantly over the past 32 years.

Amidst decreasing employment prospects and broken psychological contracts (Chrobot-Mason, 2003), one explanation for these findings is that African American students value employers who provide opportunities for skill development, meaningful employment experiences, social impact in the work, and specialized training, more than white students. In fact, given recent data from the Bureau of Labor Statistics shows that the average employee job tenure spans about 4.6 years, this might imply that applicants are evaluating employment opportunities on work attributes that provide immediate benefit to one's career growth and assist with overall employment mobility (Bureau of Labor Statistics, 2014).

Another explanation for these findings rests in the possibility that African Americans still encounter serious employment barriers due to lingering effects of prejudice, discrimination, and lack of opportunity structure (Loury, 1998). Organizations seeking to enhance the diversity of their workforce and value pluralism would do well to focus on attributes that are of greatest importance to African Americans and other diverse labor force groups. Aligning unique employer strengths with applicant preferences could help overcome the normalized effects of diversity recruitment practices, and therefore enable applicants to more easily discern differences between employers on the presence of criteria that may improve applicants' decisions to accept employment and perceptions of fit. For instance, although the need for clear rules and procedures emerged as the largest statistically significant difference between black and white students, ratings of black students on this attribute might actually reflect concerns about general issues of fairness and justice (Chapman et al., 2005). Unfortunately, this aspect of the work environment is not usually made explicit in the context of existing recruitment efforts other than to reference commitments to Equal Employment Opportunity. However, if organizations emphasized the significance of merit-based achievement, and clarified procedures used to guide major personnel decisions, then this might alleviate potential concerns of being treated unjustly (Greenhaus, Parasuraman, \& Wormley, 1990). This is especially true given that many minority applicants feel their performance will be evaluated on criteria that fall outside the scope of established objective standards or procedures (Roberson, Deitch, Brief, \& Block, 2003).

Our conceptualization of the relationship between race and job attribute preference, which includes ethnic identity, contributes to the literature by specifying a motivational mechanism that explains the racial difference in job attribute preferences of African Americans and whites. The significance of this research is that it not only provides empirical support for the role of ethnic identity in the broader context of the career development literature, but it establishes evidence that ethnic identity may significantly impact judgments and motivations attached to career-seeking behaviors. From this perspective, our study provides initial empirical support that ethnic identity should be considered more broadly in the context of job attraction and recruitment literatures.

The finding that perceptions of self-confidence were found to interact with ethnic identity to predict job attribute preferences is particularly important to our understanding of variable relationships. As shown by the interaction plot, higher levels of self-confidence tended to correlate with more positive evaluations of job attribute preferences. Interestingly, because this was not evident for those scoring lower in levels of confidence, it could be the case that job attributes are still very much influenced by one's level of confidence, but these effects are simply more pronounced when ethnic identification is stronger. This might mean that as people have more positive experiences when exploring their ethnic identity, they may also experience more identity-confirming information, which in turn translates to higher levels of confidence in their decisions about their needs in potential employment. Therefore, it might be argued that self-confidence is an important indicator of whether ethnic identity is advancing toward an "achieved" identity. Phinney and Ong (1999) argue that an achieved identity is an important base for positive self-esteem and positive role experiences. Our research thus helps uncover one potential psychological variable that has been traditionally masked by use of racial categories in comparative studies (Helms, 1994). 


\section{Study Limitations}

The primary limitation of this study is that we are unable to report a causal conclusion, because random assignment and manipulation of independent variables did not occur. It is quite possible that an alternative model exists that varies both in temporal sequencing and order. However, this research is instructive because it aimed to assess the psychological mechanisms underlying racial comparative studies of job attribute preferences, and therefore sheds light on an explanatory variable that could be useful to career and organizational attraction researchers.

Another limitation is the lack of objective measures, or a scenario that actually draws on simulated job positing. A simulation might have provided a more rigorous examination that moves job attribute preferences from the realms of "ideal" attributes to those actually offered by a potential employer. Job applicants might make different choices as they calibrate their preferences with those attributes offered by an actual employer. We imagine applicants make a complex set of tradeoffs when faced with a job decision. Various job attribute preferences may take on different weights and meanings as people evaluate what they might colloquially refer to as their "deal breakers." Context matters significantly here.

Finally, though ethnic identity fully mediates the relationship between race and job attribute preferences, there may be other variables in the background that affect the nature of these relationships that is, there may be other unidentified psychological or contextual variables not represented in this conceptualization. It might also be the case that ethnic identity search, as a process variable, may not adequately capture variance for those who have a committed or achieved identity. Exploring such identities might be more informative to evaluations of job attribute preferences than exploring ethnic identity alone. Moreover, exploration may be different from identity salience. A salient ethnic identity might influence decisions on vocational choice differently than ethnic identity exploration alone. These are important considerations for future research, and should be considered in related investigations.

\section{CONCLUSION}

The results of this study are helpful to researchers and practitioners aiming to understand effective recruitment techniques of diverse personnel. We recommend that future research distinguish between dispositional qualities of ethnic identity and those that might apply to the observance of important contextual factors. Examples of such factors include the use of promotional materials that prime more positive aspects of ethnic identity, such as a commitment to diversity and opportunities to grow. It is also possible that, as certain job attributes satisfy lower-level needs in a person's self-concept, higher-order needs that focus on promotion or growth may emerge over time. Essentially, we would argue that ethnic identity might be a useful variable to conceptualize higher- or lower-order needs in people of diverse backgrounds. For example, some people might tend to focus on aspects of a job that emphasize security and safety as a function of either confidence or ethnic identity, whereas others might emphasize aspects tied to growth and achievement. In summary, the central goal of our research is to provide greater insight regarding the many nuances tied to racial category membership, in the hope of providing more specialized and targeted recruiting efforts to people of different backgrounds.

From the standpoint of employee needs assessments, the use of ethnic identity and self-efficacy could inform more customized approaches to job attraction in the recruitment and selection process. We also think it is important to understand whether these factors relate to intentions to quit or not accept employment because of perceived diminished access to certain job attributes. This is important in understanding the effectiveness of job recruitment strategies.

There are at least two possible directions to extend future research. First, researchers could assess particular job attributes to determine what elicits the highest (or lowest) levels of ethnic identity and confidence. Second, researchers can apply that information to help change or reformulate how job attributes are articulated or presented in the context of ongoing diversity recruitment efforts.

With the rise of diversity management programs and mandates for organizational inclusion, job attributes are the main means by which employers might effectively attract, recruit, and retain qualified personnel from diverse backgrounds. Our results show that the interpretive mechanisms underlying job 
choice are informed by racial and ethnic factors. Our study therefore lays a foundation for additional research in this area.

\section{REFERENCES}

Aiken, L. S., \& West, S. G. (1991). Multiple regression: Testing and interpreting interactions. Thousand Oaks, CA: Sage.

Aronson, J., \& Steele, C.M. (2005). Stereotypes and the fragility of human competence, motivation, and self-concept. In C. Dweck \& E. Elliot (Eds.), Handbook of Competence and Motivation. New York: Guilford.

Avery, D. R., \& McKay, P. F. (2006). Target practice: An organizational impression management approach to attracting minority and female job applicants. Personnel Psychology, 59, (1), 157187.

Avery, D. R., Tonidandel, S., Thomas, K. M., Johnson, C. D., \& Mack, D. A. (2007). Assessing the Multigroup Ethnic Identity Measure for measurement equivalence across racial and ethnic groups. Educational and Psychological Measurement, 67, (5), 877-888.

Bandura, A. (1997). Self-Efficacy: The Exercise of Control. New York: Freeman.

Baumeister, R. F., \& Leary, M. R. (1995). The need to belong: Desire for interpersonal attachments as a fundamental human motivation. Psychological Bulletin, 117, (3), 497- 529.

Beaty, D. (1990). Re-examining the link between job characteristics and job satisfaction. Journal of Social Psychology, 130, (1), 131-132.

Bell, M. (2011). Diversity in Organizations. Mason, OH: Cengage Learning.

Block, C. J., Koch, S. M., Liberman, B. E., Merriweather, T. J., \& Roberson, L. (2011). Contending With Stereotype Threat at Work: A Model of Long-Term Responses. The Counseling Psychologist, 39, (4), 570-600.

Braddy, P. W., Meade, A. W., \& Kroustalis, C. M. (2006). Organizational recruitment website effects on viewers' perceptions of organizational culture. Journal of Business and Psychology, 20, (4), 525543.

Brenner, O. C., \& Tomkiewicz, J. (1982). Job orientation of black and white college graduates in business. Personnel Psychology, 35, (1), 89-103.

Brenner, O. C., Blazini, A. P., \& Greenhaus, J. H. (1988). An examination of race and sex differences in managerial work values. Journal of Vocational Behavior, 32, (3), 336-344.

Brittian, A. S., Kim, S. Y., Armenta, B. E., Lee, R. M., Umaña-Taylor, A. J., Schwartz, S. J., \& Hudson, M. L. (in press). Do dimensions of ethnic identity mediate the association between perceived ethnic group discrimination and depressive symptoms? Cultural Diversity and Ethnic Minority Psychology.

Butler, S. A. Sanders D.E., \& Whitecotton, S.M. (2000). Student and recruiter insights on the importance of job attributes. Journal of Managerial Issues, 12, (3), 337-351.

Bureau of Labor Statistics. (2014). Employee Tenure in 2014. http://www.bls.gov/news.release/tenure.nr0.htm, Retrieved on November 28, 2014.

Byrd, D., \& Mirken, B. (2011) Post-Racial? Americans and race in the age of Obama. The Greenlining Institute http://greenlining.org/publications/2011/post-racial-americans-and-race-in-age-ofobama, Retrieved on November 28, 2014.

Carter, R. T., Gushue, G. V., \& Weitzman, L. M. (1994). White racial identity development and work values. Journal of Vocational Behavior, 44, 185-197.

Chapman, D. S., Uggerslev, K. L., Carroll, S. A., Piasentin, K. A., \& Jones, D. A. (2005). Applicant attraction to organizations and job choice: A meta-analytic review of the correlates of recruiting outcomes. Journal of Applied Psychology, 90, (5), 928-944.

Chavez, A. F., \& Guido-DiBrito, F. (1999). Racial and ethnic identity and development. New Directions for Adult and Continuing Education, 84, 39-47. 
Chrobot-Mason, D. L. (2003). Keeping the promise: Psychological contract violations for minority employees. Journal of Managerial Psychology, 18, (1), 22-45.

Chrobot-Mason, D., \& Thomas, K. M. (2002). Minority employees in majority organizations: The intersection of individual and organizational racial identity in the workplace. Human Resource Development Review, 1,(3), 323-344.

Cokley, K. (2007). Critical issues in the measurement of ethnic and racial identity: A referendum on the state of the field. Journal of Counseling Psychology, 54, (3), 224-234.

Combs, G. M., Milosevic, I., Jeung, W., \& Griffith, J. (2012). Ethnic identity and job attribute preferences: The role of collectivism and psychological capital. Journal of Leadership \& Organizational Studies, 19, (1), 5-16.

Doverspike, D., Taylor, M. A., Shultz, K. S., \& McKay, P. F. (2000). Responding to the challenge of a changing workforce: Recruiting nontraditional demographic groups. Public Personnel Management, 29, (4), 445-457.

Fouad, N. A., \& Brown, M. T. (2000). Role of race and social class in development: Implications for counseling psychology. In S.D. Brown, Steven D. \& R.W. Lent (Eds.), Handbook of counseling psychology 3rd ed., 379-408. Hoboken, NJ: John Wiley \& Sons.

Fouad, N. A., \& Byars-Winston, A. M. (2005). Cultural context of career choice: Meta-analysis of race/ethnicity differences. Career Development Quarterly, 53, (3), 223-233.

Gloria, A. M., \& Hird, J. S. (1999). Influences of ethnic and nonethnic variables on the career decisionmaking self-efficacy of college students. Career Development Quarterly, 48, (2), 157-174.

Greenhaus, J. H., Parasuraman, S., \& Wormley, W. M. (1990). Effects of race on organizational experiences, job performance evaluations, and career outcomes. Academy of Management Journal, 33, (1), 64-86.

Grills, S., \& Prus, R. (2008). The myth of the independent variable: Reconceptualizing class, gender, race, and age as subcultural processes. American Sociologist, 39, (1), 19-37.

Gushue, G. V. (2006). The relationship of ethnic identity, career decision-making self-efficacy and outcome expectations among Latino/a high school students. Journal of Vocational Behavior, 68, (1), 85-95.

Gushue, G. V., \& Whitson, M. L. (2006). The relationship among support, ethnic identity, career decision self-efficacy, and outcome expectations in African American high school students applying social cognitive career theory. Journal of Career Development, 33, (2), 112-124.

Hayes, A. F., Glynn, C. J., \& Huge, M. E. (2012). Cautions regarding the interpretation of regression coefficients and hypothesis tests in linear models with interactions. Communication Methods and Measures, 6, (1), 1-11.

Hayes, A. F., Preacher, K. J., \& Myers, T. A. (2011). Mediation and the estimation of indirect effects in political communication research. In E. P. Bucy \& R. L. Holbert (Eds.), The sourcebook for political communication research: Methods, measures, and analytical techniques (pp. 434-465). New York: Routledge.

Helms, J. E. (1993). Introduction: Review of Racial Identity Terminology. In J. E. Helms (ed.), Black and White Racial Identity: Theory, Research and Practice. Westport, Conn.: Praeger.

Helms, J. E. (1994). Racial identity and career assessment. Journal of Career Assessment, 2, (3), 199209.

Helms, J. E., \& Piper, R. E. (1994). Implications of racial identity theory for vocational psychology. Journal of Vocational Behavior, 44, (2), 124-138.

Helms, J. E., \& Talleyrand, R. M. (1997). Race is not ethnicity. American Psychologist, 52, (11), 12461247.

House, J. S., \& Williams, D. R. (2003). Understanding and reducing socioeconomic and racial/ethnic disparities in health. In R. Hofrichter (ed.), Health and Social Justice: Politics, Ideology, and Inequity in the Distribution of Disease. San Francisco, CA: Jossey-Bass.

Hughes, M., \& Demo, D. H. (1989). Self-perceptions of Black Americans: Self-esteem and personal efficacy. American Journal of Sociology, 95, (1), 132-159. 
Jones, J. and Schmitt, J. (2014). A College Degree is No Guarantee. Working Paper, Center for Economic and Policy Research.

Karasek, R., \& Bryant, P. (2012). Signaling theory: past, present and future. Academy of Strategic Management Journal, 11, (1), 91-99.

Kim, S. S., \& Gelfand, M. J. (2003). The influence of ethnic identity on perceptions of organizational recruitment. Journal of Vocational Behavior, 63, (3), 396-416.

Konrad, A. M., Ritchie Jr, J. E., Lieb, P., \& Corrigall, E. (2000). Sex differences and similarities in job attribute preferences: a meta-analysis. Psychological Bulletin, 126, (4), 593-641.

Lee, I. H., \& Rojewski, J. W. (2009). Development of occupational aspirations prestige: A piecewise latent growth model of selected influences. Journal of Vocational Behavior, 75, (1), 82-90.

Leong, F. T., \& Chou, E. L. (1994). The role of ethnic identity and acculturation in the vocational behavior of Asian Americans: An integrative review. Journal of Vocational Behavior, 44, (2), $155-172$.

Lillevik, W., Combs, G. M., \& Wyrick, C. (2010). Managing diversity in the USA: The evolution of inclusion in the workplace. In A. Klarsfeld (ed.), International Handbook on Diversity Management at Work: Country Perspectives on Diversity and Equal Treatment. Cheltenham, UK: Edward Elgar.

Linnehan, F., Chrobot-Mason, D., \& Konrad, A. M. (2006). Diversity attitudes and norms: The role of ethnic identity and relational demography. Journal of Organizational Behavior, 27, (4), 419-442.

Loury, G. C. (1998). Discrimination in the post-civil rights era: Beyond market interactions. Journal of Economic Perspectives, 12, (2), 117-126.

Luthans, F., Youssef, C. M., \& Avolio, B. J. (2007). Psychological Capital. Thousand Oaks, CA: Sage.

Manhardt, P. J. 1972. Job orientation of male and female college graduates in business. Personnel Psychology, 25, (2), 361-368.

McDermott, M., \& Samson, F. L. (2005). White racial and ethnic identity in the United States. Annual Review of Sociology, 31, 245-261.

McKay, P. F., \& Avery, D. R. (2005). Warning! Diversity recruitment could backfire. Journal of Management Inquiry, 14, (4), 330-336.

McKay, P. F., Avery, D.R., Tonidandel, S., Morris, M.A., Hernandez, M. A., \& Hebl, M. R. (2007). Racial differences in employee retention: Are diversity climate perceptions the key. Personnel Psychology, 60, (1), 35-62.

Meyer, J. P., Irving, P. G., \& Allen, N. J. (1998). Examination of the combined effects of work values and early work experiences on organizational commitment. Journal of Organizational Behavior, 19, (1), 29-52.

Neblett Jr, E. W., Banks, K. H., Cooper, S. M., \& Smalls-Glover, C. (2013). Racial identity mediates the association between ethnic-racial socialization and depressive symptoms. Cultural Diversity and Ethnic Minority Psychology, 19, (2), 200-207.

Oyserman, D., \& Destin, M. (2010). Identity-based motivation: Implications for intervention. Counseling Psychologist, 38, (7), 1001-1043.

Oyserman, D., Brickman, D., Bybee, D., \& Celious, A. (2006). Fitting in matters: Markers of in-group belonging and academic outcomes. Psychological Science, 17, (10), 854-861.

Oyserman, D., Uskul, A., Yoder, N., Nesse, R., \& Williams, D. (2007). Unfair treatment and selfregulatory focus. Journal of Experimental Social Psychology, 43, (3), 505-512.

Phinney, J. S. (1992). The multigroup ethnic identity measure: A new scale for use with diverse groups. Journal of Adolescent Research, 7, (2), 156-176.

Phinney, J. S., \& Alipuria, L. L. (1996). At the interface of cultures: Multiethnic/multiracial high school and college students. Journal of Social Psychology, 136, (2), 139-158.

Phinney, J. S., \& Ong, A. D. (2007). Conceptualization and measurement of ethnic identity: Current status and future directions. Journal of Counseling Psychology, 54, (3), 271-282.

Richard, O. C. (2000). Racial diversity, business strategy, and firm performance: A resource-based view. Academy of Management Journal, 43, (2), 164-177. 
Roberson, L., Deitch, E. A., Brief, A. P., \& Block, C. J. (2003). Stereotype threat and feedback seeking in the workplace. Journal of Vocational Behavior, 62, (1), 176-188.

Roberson, Q. M. (2006). Disentangling the meanings of diversity and inclusion in organizations. Group \& Organization Management, 31, (2), 212-236.

Rynes, S.L. and Boudreau, J.W. (2006). College recruiting in large organizations: Practice, evaluation and research implications. Personnel Psychology, 39, (4), 729-757.

Rynes, S. L., Heneman, H. G., III, \& Schwab, D. P. (1980). Individual reactions to organizational recruiting: A review. Personnel Psychology, 33, (3), 529-542.

Sutherland, J. (2012). Qualifications mismatch and skills mismatch. Education + Training, 54, (7), 619632.

Swanson, R. R., \& Prelow, H. M. (2005). Ethnic identity, self-esteem, and perceived efficacy as mediators of the relation of supportive parenting to psychosocial outcomes among urban adolescents. Journal of adolescence, 28, (4), 465-477.

Turban, D. B. (2001). Organizational attractiveness as an employer on college campuses: An examination of the applicant population. Journal of Vocational Behavior, 58, (2), 293-312.

Turban, D. B., \& Dougherty, T. W. (1992). Influences of campus recruiting on applicant attraction to firms. Academy of Management Journal, 35, (4), 739-765.

Turban, D. B., Eyring, A. R., \& Campion, J. E. (1993). Job attributes: Preferences compared with reasons given for accepting and rejecting job offers. Journal of Occupational and Organizational Psychology, 66, (1), 71-81. 